\title{
How does business power operate? A framework for its working mechanisms
}

\author{
Milan Babic $1,2,3 *$ (D), Jouke Huijzer ${ }^{4}$, Javier Garcia-Bernardo ${ }^{2,5}$ and Diliara Valeeva ${ }^{6}$ \\ ${ }^{1}$ Faculty of Social Sciences, Maastricht University, Maastricht, The Netherlands, ${ }^{2}$ Amsterdam Institute for Social Science \\ Research, University of Amsterdam, Amsterdam, The Netherlands, ${ }^{3}$ Department of Department of Social Sciences and Business, \\ Roskilde University, DK-4000 Roskilde, Denmark, ${ }^{4}$ Department of Political Science, Free University Brussels, Brussels, Belgium, \\ ${ }^{5}$ Social and Behavioural Sciences, Social Data Science (SoDa) Team, Utrecht University, Utrecht, The Netherlands and \\ ${ }^{6}$ Department of Geography and Tourism, KU Leuven, Belgium \\ ${ }^{\star}$ Corresponding author: Milan Babic, Email: babic@ruc.dk; m.babic@maastrichtuniversity.nl
}

\begin{abstract}
The global financial crisis of 2008, its following bank bailouts, and associated corporate impunity sparked a renewed interest in the concept of the structural power of business and the question of "who rules?" in capitalist societies. This new wave of scholarship mitigated some of the problems of the original, theory-driven discussions from the 1970s and 1980s. But despite significant advancements in the empirical identification of business power, we lack a unified framework for studying its working mechanisms. So-called hybrid approaches, drawing on instrumental and structural power for their analyses, display high potential for such a unified and easily applicable framework. We build on this hybrid tradition and propose a novel model that integrates instrumental and structural power analysis into a basic framework. With this, we recalibrate the often rigid division between instrumental and structural power forms and emphasize the role of perceptions as key for understanding the dynamics of business power over time. We illustrate this parsimonious framework by an analysis of the plans of the Dutch government to abolish a dividend tax in 2018 that would have benefited a number of large multinationals but collapsed before implementation.
\end{abstract}

Keywords: business power; structural power; instrumental power; tax; political economy

\section{Introduction}

Corporate power is back on the table of academic research. The politics of bank bailouts and the associated corporate impunity after the Global Financial Crisis (GFC) triggered a renewed interest in the power of big business. A decade later, multiple research agendas on corporate power have emerged: among others, on the power of finance during postcrisis banking regulation efforts; ${ }^{1}$ on the firm as

\$We dedicate this paper to Meindert Fennema and Eelke Heemskerk, mentors and friends, and the whole CORPNET project. We thank Jan Fichtner, Eelke Heemskerk, Wouter Schakel, Herman Mark Schwartz, Frank Takes, and three anonymous reviewers for valuable feedback on previous versions of this article. We also express our gratitude to the organizers and participants of the panels "Network Analysis, Complex Interdependence, and Structural Power in the Global Political Economy" at the ISA 2018 in San Francisco and "States of Capital" at the IIPPE conference 2019 in Lille as well as the Political Economy Working Group at the EUI Florence, where this paper was presented. MB, JGB, and DV have received funding from the European Research Council (ERC) under the European Union's Horizon 2020 research and innovation program (grant agreement number 638946). MB has received further funding from the ERC under the European Union's Horizon 2020 research and innovation program (grant agreement number 758430).

${ }^{1}$ Woll (2016).

(C) The Author(s), 2022. Published by Cambridge University Press on behalf of V.K. Aggarwal. This is an Open Access article, distributed under the terms of the Creative Commons Attribution-NonCommercial-NoDerivatives licence (https://creativecommons.org/licenses/by-nc-nd/4.0/), which permits non-commercial re-use, distribution, and reproduction in any medium, provided the original work is unaltered and is properly cited. The written permission of Cambridge University Press must be obtained for commercial re-use or in order to create a derivative work. 
a site of power struggles; ${ }^{2}$ or on the role of corporate power in international politics. ${ }^{3}$ This revival of corporate power research also brought back old questions that scholars tackled with new tools.

The most prominent issue that underwent such a renaissance is the concept of structural power. In the decades before the crisis, structural power had a "labeling problem, if not a toxic brand name recognition," not at least due to its roots in Marxist political economy. What is more, extensive and often self-referencing, sometimes highly abstract, discussions about whether or not "capital rules" unfettered in capitalist societies made structural power a rather sidelined issue in political science research. With the GFC and the subsequent bailouts of banks that were deemed "too big to fail," the (structural) power of business experienced an academic renaissance.

A special issue of Business \& Politics, edited by Pepper Culpepper, ${ }^{5}$ brought these postcrisis efforts together by outlining a broad research agenda on structural power. Different from the old, theorybuilding discussions, these recent contributions treat the concept of structural power mostly as an independent variable with measurable empirical effects. This new empirical interest is consequently more focused on specific structural power relations, for example between particular firms or sectors and certain government branches, instead of generalized statements about state-business relations in capitalism. This empirical turn in research on structural power produced a number of high-quality studies that have provided valuable insights in what happens inside the black box of state-business relations, thereby rehabilitating structural power as a serious tool for political analysis. ${ }^{6}$

Along with the revival of the concept of structural power, the (old) question of how to distinguish its effects from instrumental power has become a core concern again. How can we be certain that a particular outcome is the consequence of the structural power of business, rather than brought about by revolving doors or lobbying activity? Methodologically, some studies attempt to assess this from the angle of the outcomes of political processes: by systematically eliminating alternative explanations in well-defined cases of the political success of business, only structural power remains as an explanandum. Others have developed more hybrid approaches by theoretically bridging the distinction by either paying more theoretical attention to the instrumental activity of "structurally prominent" business actors ${ }^{7}$ or by discussing the interplay and mutual reinforcement of instrumental and structural power. Recent studies conceptualized such hybrid approaches and demonstrated their usefulness as critical tools for a better empirical understanding of business power. ${ }^{8}$ These studies showed impressively that a convincing and empirically saturated analysis of policy processes needs to incorporate both forms of business power.

In this contribution, we seek to advance the theoretical and methodological discussion of such hybrid approaches of business power. By proposing a unified framework for empirical analysis, we go beyond existing hybrid approaches by recalibrating an often too rigid distinction between structural and instrumental power. More precisely, we consider structural power as the result of a particular constellation of multiple dyadic power relationships, which we explain closer in the following. Such an approach offers a range of theoretical advantages: First, it allows us to establish and integrate the perceptions of policy makers and how they are shaped as the crucial aspect for the empirical study of business power. While authors in the constructivist tradition have long emphasized the important role of the perceptions of the agents that are subject to power, this insight has yet to be adequately integrated into a hybrid framework. Second, our approach allows us to trace change and temporal variation in the degree of business power within and across cases. This fills an important gap in the existing research on especially structural power, which was often criticized for being a static independent variable. Third, we introduce a basic model of business power, which is easily applicable to many cases of state-business relations. We deliberately create a simplified, parsimonious model, which is open for extension and adaptation beyond

\footnotetext{
${ }^{2}$ Baars and Spicer (2017).

${ }^{3}$ Fuchs (2013); Babic et al. (2017).

${ }^{4}$ Culpepper (2015).

${ }^{5}$ Ibid.

${ }^{6}$ See, e.g., Bell (2012); Bell and Hindmoor (2014); Fairfield (2015a); Bell and Hindmoor (2017).

${ }^{7}$ See, e.g., Young (2015).

${ }^{8}$ See especially Hacker and Pierson (2002), Fairfield (2015a, 2015b), and Culpepper and Reinke (2014).
} 
the empirical example we discuss. To illustrate our approach, we analyze the recent case of the Dutch dividend tax debate, which ended in an unexpected defeat of big business and therefore holds important insights for the working mechanisms of business power as an empirical phenomenon.

The article proceeds as follows: First, we outline the conceptualizations of business power in the instrumental and structural power traditions ("Structural and Instrumental Business Power"). Second, we discuss existing hybrid approaches in the literature and their limitations ("Hybrid Approaches and Their Limits"). Third, we introduce a basic framework for analyzing business power that builds on the discussion and critique of hybrid accounts ("The Working Mechanisms of Business Power"). Fourth, we illustrate our approach empirically with a case study on the mentioned failure of the abolishment of the Dutch dividend tax in 2018 ("The Case of the Dutch Dividend Tax Debate"). Finally, we discuss the case study results and reflect upon how our model can be adapted to facilitate future empirical research ("Discussions and Conclusions").

\section{Structural and instrumental business power}

The distinction between instrumental and structural power emerged with the debates on the capitalist state in the 1970s and 1980s. Back then, the key disputes evolved around the question whether the control of (democratic) state apparatuses or the ownership of capital was the ultimate source of power in capitalist societies. ${ }^{9}$ So-called instrumentalists argued that by owning the means of production and holding key positions in state institutions, capitalists are able to use these state apparatuses to control and direct policies in favor of capital accumulation. ${ }^{10}$ By contrast, so-called structuralists emphasized the privileged position capital enjoys in market societies. States need to cater to business interest as the latter may otherwise divest or lay off workers, which undermines the general welfare of a society. As government officials have to anticipate reactions of businesses, states cannot be an instrument of the class in power, but they serve as stabilizers and managers of capitalist accumulation, especially with regard to crises. ${ }^{11}$

The standoff between instrumentalists and structuralists reflects the most fundamental distinction within the literature on business power. As Fuchs and Lederer argue, the literature is mainly shaped by the distinction between instrumental and what they call "structural and discursive approaches."12 The instrumentalist approach holds that specific actors (i.e., businesses) actively, consciously, and often collectively attempt to influence the decisions of another actor (i.e., the state). Business can exercise power over society by direct participation in and "capture" of state institutions; ${ }^{13}$ but political campaign donations, ${ }^{14}$ participation in advocacy groups, and lobby activity ${ }^{15}$ are also typically considered to be manifestations of instrumental power. ${ }^{16}$ Different from this focus on observable relations, Fuchs and Lederer subdivide structural power in ideational (or discursive) and material structural power. In a material sense, the structural power argument holds that because it is the capitalists who decide over (dis-)investment, jobs, and prices-and thus over societal welfare-state and society are structurally (i.e., by default) dependent on their decisions. ${ }^{17}$ The capitalist structure of market societies limits the agency options of the state insofar as it is not possible to raise taxes indefinitely and at the same time hope for incoming investment, economic growth, and employment of the population. ${ }^{18}$ Structural power follows from such a form of structural dependence: capitalists can exert pressure, threaten, and enforce their interests indirectly vis-à-vis state and society, which yields business a

\footnotetext{
${ }^{9}$ Barrow (1993, 24).

${ }^{10}$ ibid., 16. See also Miliband (1969).

${ }^{11}$ Barrow (1993, 51). See also Poulantzas (1968).

${ }^{12}$ Fuchs and Lederer (2007, 3); See also Fuchs (2013).

${ }^{13}$ Miliband (1969, 54).

${ }^{14}$ Wright (2003); Burris (1987).

${ }^{15}$ Richardson (2000); Getz (1997).

${ }^{16}$ Fuchs and Lederer $(2007,4-5)$.

${ }^{17}$ Przeworski and Wallerstein $(1988,12)$.

${ }^{18}$ Ibid., 13 .
} 
Table 1: Ideal types of instrumental and structural power

\begin{tabular}{lcc}
\hline & Instrumental power & Structural power \\
\hline \multirow{2}{*}{ Causal mechanism } & Direct & Indirect \\
\cline { 2 - 3 } & Organized & Disorganized \\
\hline Role of state actors & Officials matter & Officials do not matter \\
\cline { 2 - 3 } & State institutions matter & State institutions do not matter \\
\hline Ontological status & Dyadic & Diffuse \\
\hline Methodological status & Concrete & Abstract \\
\hline & Methodological individualism & Methodological holism \\
\cline { 2 - 3 } & Observable & Unobservable
\end{tabular}

privileged position in society. ${ }^{19}$ In an ideational sense, structural dependence manifests itself as a discourse in which taking into account the interest of business then equals taking care of the whole society, which should be the purpose of governmental politics.

The distinction is summarized in an ideal-typical way in table 1. In a nutshell, instrumental power is usually regarded as a more direct, observable, and concrete form of power exercise, while structural power is often understood as an indirect, hardly observable, and rather abstract power type.

One of the core problems the early discussions faced was their relatively strong theoretical abstraction and consequently their limited empirical applicability. It was often held against the structural power argument that business does not "win" all its political disputes by default and that, to the extent that it enjoys a privileged position, this is highly circumstantial. Scholars also argued that because structural power (presumably) denies variation in outcomes but empirical research demonstrates this variation, research efforts aimed at exactly this type of institutional and political variation were simply not interested in such a "clunky variable." 20

In an effort to counter the criticisms, several scholars have nuanced the picture by identifying two further key aspects that enhance business power. A first one is the existence of a so-called exit option for business such as a different tax regime in another jurisdiction. If the costs of moving abroad are low, business may be able to influence the state by threatening to leave. Exit options became an oftencited reference point not only in academic debates but also in the political discussion around the impacts of globalization on the agency options of the nation-state in the global race for attracting foreign direct investment.

The second factor is that structural power is conditional upon exogenous circumstances affecting the general state of the economy, such as a major war, epidemic, or an economic depression, that can mediate the structural power of business. The precise effect of such external events can vary in different instances. But often they limit the capacity by states to provide tax breaks or they require cooperation for specific ends that make "normal" distributional struggles (temporarily) less central. Structural power is thus not only a relation between capital and the state but also conditioned by exogenous factors.

\section{Hybrid approaches and their limits}

Within the recent wave of structural power research, scholars have developed a number of theoretical and empirical innovations to remedy the shortcomings of the early discussions. Among those accounts, so-called hybrid approaches aimed to integrate both instrumental and structural perspectives on business power. This integration has been identified as one of the most relevant tasks within the empirical turn of business power research: taking into account the interaction of instrumental and

\footnotetext{
${ }^{19}$ Lindblom (1977). See also Fairfield (2015b).

${ }^{20}$ Culpepper $(2015,392)$.
} 
structural power creates leverage for explaining empirical variation within and across cases. ${ }^{21}$ Hybrid approaches are best-suited for this task, as they integrate empirically observable instrumental and harder-to-observe structural power relations into their explanatory frameworks to explain continuity and change of business power. ${ }^{22}$

Those hybrid approaches can be broadly grouped in two strands: on the one hand, the "power resources" perspective holds that structural factors constrain and position various actors in political struggles, after which a political battle unfolds that can be grasped using more instrumentalist perspectives. ${ }^{23}$ While this approach acknowledges the role of both instrumental and structural factors, it leaves the analytical distinction largely intact. On the other hand, a second strand emphasizes the role of ideational and discursive factors, the saliency of certain topics and the agency of various actors to influence this "power of ideas." ${ }^{24}$ Our contribution attempts to systematize the latter approach, while recalibrating the often rigid distinction between structural and instrumental power of the power resources approach.

\section{Power resources and economic constraints}

Let us first examine the power resources approach more closely. This line of theorizing emerges from Hacker and Pierson who argued that structural power should foremost be regarded as a "signaling device" and not as a "dictate of policy choices." ${ }^{25}$ Hence, they state that:

[T] he prospect or actuality of disinvestment can set the agenda for governments and help to define (or rule out) alternatives, but this signal cannot tell governments what to do. The extent to which business influences specific policy choices will be a function of instrumental rather than structural power. ${ }^{26}$

In this vein, Young has introduced the concept of "structural prominence" as an alternative to structural power because it leaves more space for agency and "instrumental activity" in state-business relations. ${ }^{27}$ The power resources approach holds that some actors such as companies, sectors, or business associations may be more structurally prominent and thus better positioned to exert power. However, whether these actors do so remains contingent and dependent upon specific instrumental activity. Just as having the better hand in a card game may increase the chance of winning, it does not guarantee victory as this may also depend upon the sequence in which they are played. ${ }^{28}$

Various studies that mostly focus on the interplay of structural and instrumental power have articulated further important aspects. Hindmoor and McGeechan shift the attention to the temporal horizon that is crucial for studying the interplay of structural and instrumental power. ${ }^{29}$ Instrumental activity may result in legal changes that enable certain actors to increase their structural power, or prominence, over a certain period. Culpepper and Reinke then aim to break with the "single dichotomy" ${ }^{30}$ of structural and instrumental power by distinguishing between automatic and more strategic manifestations of both forms. They hold that existing research too often relied on an abstract notion of structural power, which emphasized its automatic aspects. Consequently, they suggest looking at the more strategic use of this structural power to understand variation in policy outcomes.

\footnotetext{
${ }^{21}$ Fairfield (2015a, 411).

${ }^{22}$ See, e.g., Culpepper and Reinke (2014).

${ }^{23}$ See, e.g., Hacker and Pierson (2002); Young (2015); Fairfield (2015a, 2015b).

${ }^{24}$ See, e.g., Bell (2012); Bell and Hindmoor (2014).

${ }^{25}$ Hacker and Pierson $(2002,282)$.

${ }^{26}$ Ibid.

${ }^{27}$ Young (2015).

${ }^{28}$ We borrow the card game analogy from Culpepper and Reinke (2014).

${ }^{29}$ Hindmoor and McGeechan (2013).

${ }^{30}$ Culpepper and Reinke $(2014,431)$.
} 
At the same time, a well-founded criticism against such a focus on power resources is that the ideational aspect of power relations is almost absent. ${ }^{31}$ The shaping and content of ideas is, however, an important aspect of how actors perceive the power position of others, and hence their own room for maneuver. The most advanced attempt to integrate ideational factors into the power resources approach is provided by Fairfield. ${ }^{32}$ She considers structural power mostly as an economic constraint that demarcates the possibilities that a government may have to, for instance, raise taxes. Fairfield takes into account ideational factors by stating that structural power crucially depends on the perceptions of policy makers of business power "regardless of the actual impact." ${ }^{33}$ Fairfield regards discursive or ideational power as instrumental power as it mostly comprises of "media access, technical expertise, and informal ties to policymakers." 34 This instrumental view on discursive power is, however, only one aspect of the ideational dimension of business power. As ideational approaches articulate, changing dominant ideas is often more about shaping public perceptions (or discourses) than simply directly influencing policy makers. It is therefore important to analytically distinguish between discursive/ideational influence and more direct instrumental power relations as we do in the following ("The Working Mechanisms of Business Power.") In addition, Fairfield also maintains a strict analytical distinction between instrumental and structural power. Both forms of power can have "additive effects"; 35 and they can be understood as "forces acting in the same direction." 36 Our conceptualization takes this a step further and integrates both forms of power into a single, unified framework to excavate their coconstitutive effects.

\section{Agency and ideational structural power}

The other strand of the more hybrid approaches goes beyond the power resources approach by introducing ideas and discourses as a major explanatory factor. This is done through emphasizing the ideational aspects of structural power by focusing on perceptions and discourses. Bell articulates how structural power is conditioned by the "ideational shaping" of the otherwise "too structuralist" concept of structural power. ${ }^{37}$ Drawing from several constructivist theoretical strands, Bell argues that the structural power of business is often mediated by the perceptions and preferences of government officials. In the card game metaphor, it depends which cards are deemed better because perceptions, priorities, and whether actors agree upon the rules may differ and be subject to change.

Importantly, ideational approaches emphasize the agency that is involved in shaping the perceptions of key actors, such as government officials. In earlier work, Culpepper had already noted that business is likely to engage in "quiet politics"38 as increased saliency of an issue usually reduces business power. This leverages ideational arguments, as saliency is not a power resource, but a factor shaping the perceptions of actors. Yet, as was pointed out in debates on the introduction of a mining tax in Australia, ${ }^{39}$ whether the saliency of a proposal truly diminishes business power strongly depends upon whether the public perceives taxes to work in its interest. Business actors can attempt to influence these perceptions with media appearances or by funding campaigns to influence public opinion.

Despite the emphasis on "agency" for the efficacy of structural power, most ideational accounts fall short of integrating instrumental and structural power in a unified framework. It is acknowledged that "business power is ... operating through structural and instrumental channels" 40 and that both "can

\footnotetext{
${ }^{31}$ Marsh et al. $(2015,593)$.

${ }^{32}$ Fairfield (2015b).

${ }^{33}$ Ibid., 44.

${ }^{34}$ Fairfield (2015b, 52).

${ }^{35}$ Fairfield (2015a, 421).

${ }^{36}$ Ibid.

${ }^{37}$ Bell $(2012,662)$.

${ }^{38}$ Culpepper (2011).

${ }^{39}$ See Marsh et al. (2014); Bell and Hindmoor (2014).

${ }^{40}$ See, e.g., Bell and Hindmoor $(2017,106)$.
} 
often work together" ${ }^{41}$ or "run together in the real world." ${ }^{42}$ However, how exactly this interaction takes place is rarely explicated in ideational accounts, which pay more attention to the dynamics between structural power and ideas. ${ }^{43}$

In sum, the power resources literature clearly demonstrates the importance of incorporating both instrumental and structural power in convincing explanatory frameworks; while the ideational approaches emphasize the discursive shaping and malleability of (perceived) structural power positions and government priorities. We build on both strands of theorizing and integrate them in our framework. We thereby go beyond the former by emphasizing the co-constitutive nature of instrumental and structural power rather than their analytical distinction; and we go beyond the latter by extending its insights beyond structural power only, but toward business power as a general phenomenon.

\section{The working mechanisms of business power}

As discussed, both hybrid strands offer important insights for the working mechanisms of business power. At the same time, both hold on to an analytical separation of instrumental and structural power, despite calls to "be extremely wary of thinking of instrumental and structural power as some-

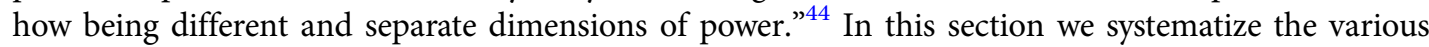
ways in which business exerts power over other actors into a unified framework. We reconceptualize business power by recalibrating the structural and instrumental power distinction and moving the discussion forward.

\section{Rethinking the structural and instrumental power distinction}

We argue that the persisting analytical distinction between instrumental and structural power of business arises mainly from a difference in focus of each form. Instrumentalist accounts tend to focus on the agents-usually businesses - and their capacity to exercise power over the state. Structural accounts, by contrast, focus on the targets over which power is exercised-usually the state-and how they negotiate different conflicting interests. To be clear, we do not argue that no distinction between structural and instrumental power can be made, or that this distinction should be abandoned. Rather, we believe that articulating the co-constitution of structural and instrumental power on the basis of multiple dyadic power relations facilitates a more complete analysis of business power and its spatio-temporal variations. We first argue that structural power in a material sense emerges from particular working mechanisms or constellations of dyadic power relations.

To substantiate this, let us begin with a common definition of power as "the capacity to make another do something that that person would not otherwise do or as the exercise of such a capacity." 45 This definition unproblematically fits the instrumental approaches because the relation it describes is dyadic, direct, and observable. Whereas lobbying power denotes a direct instrumental relationship between capital and the state, (material) structural power can, in the first instance, be represented as two dyadic power relations. In capitalist democracies, big business enjoys a direct power relation (or instrumental capacity) over its employees; whereas employees, as citizens, have a direct power relation over the state as they can elect its representatives. If this elected government does not cater to the interests of big business-for instance by lowering taxes-businesses may suspend investment or lay off employees. Those can, in return, express their dissatisfaction by voting for a different administration. In other words, "vote-seeking politicians are dependent on owners of capital because voters are." 46

At first glance, the material structural power of business can thus be expressed in the form of two dyadic power relations (or instrumental capacities). We illustrated those power relations from the

\footnotetext{
${ }^{41}$ Ibid.

${ }^{42}$ Ibid.

${ }^{43}$ See also Bell $(2012,672)$, who dedicates only one short paragraph to instrumental power in his ideational account.

${ }^{44}$ Hindmoor and McGeechan $(2013,846)$.

${ }^{45}$ Haugaard $(2014,1)$.

${ }^{46}$ Przeworski and Wallerstein $(1988,12)$.
} 


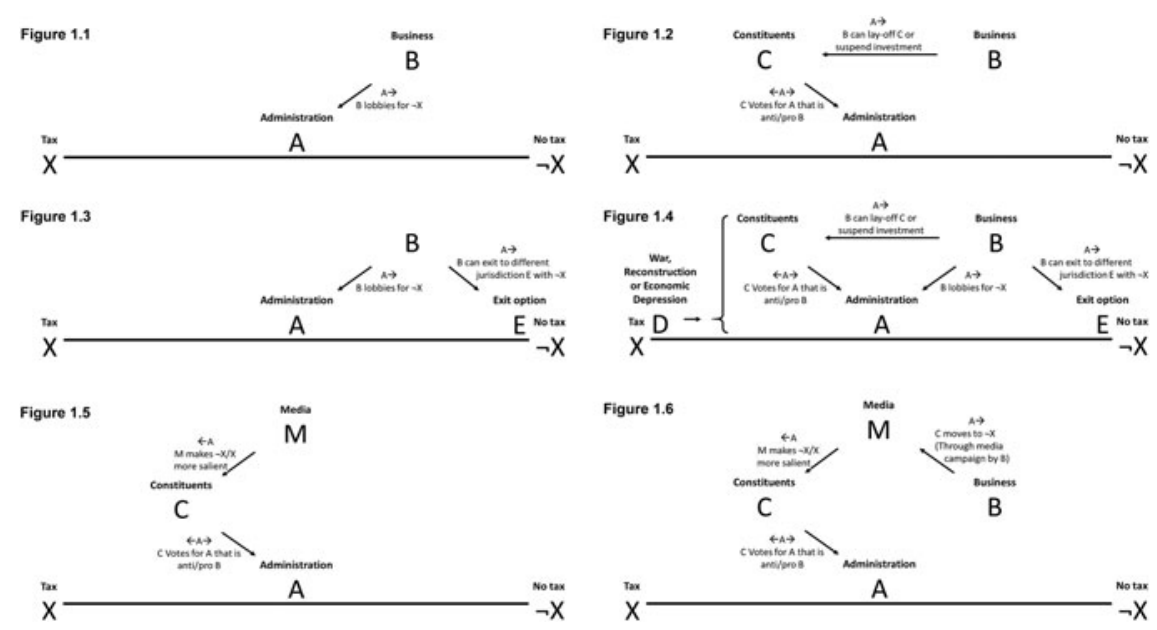

Figure 1: Visualization of the working mechanisms of business power based on the existing literature. $A \rightarrow / \leftarrow A$ indicates, in which direction (tax or no tax in our example) the administration goes depending on the power of business and other societal actors at a given point in time.

perspective of business in figure 1. Figure 1.1 represents what is normally understood as the instrumental form of business power (e.g., lobbying or revolving doors), while figure 1.2 depicts its structural manifestation. We can see that the material structural power relations can be represented as a finite number of dyadic power relationships (the arrows in figure 1.2). If administration A wants to change a tax affecting business, it has to take a position on the continuum that ranges from introducing or increasing a tax $(\mathrm{X})$ to lowering or abolishing it $(\neg \mathrm{X})$. As in figure 1.1, lobbying efforts on behalf of business (B) may pull A to the right (toward $\neg \mathrm{X}$ ), while constituents $(\mathrm{C})$ may prefer higher taxation. However, if the result is that increasing taxes leads to layoffs by $\mathrm{B}$, which has direct (instrumental) power over $\mathrm{C}$ (the power to fire employees), the administration (A) may still not follow up on the wishes of the constituents $(\mathrm{C})$, fearing that they will evaluate its performance differently once business (B) suspends investments. Hence, the structural power of business is not an abstract phenomenon, but can, as depicted in figure 1.2 , be deconstructed analytically into two dyadic power relationships $B \Rightarrow C$ and $\mathrm{C} \Rightarrow \mathrm{A}$. Dyadic power relations can also be called "instrumental capacities" because they denote a potential instrumental relationship: business could pull out investment, and constituents could punish the incumbent administration by voting it out of office. Both hence describe an instrumental (and often only potential) capacity.

A similar logic applies to the existence of an outside option. As long as business has a credible opportunity-or the "instruments" at hand-to move to a different jurisdiction, it may have leverage over an administration. If, however, the opportunity to move abroad or invest elsewhere ceases to exist, business no longer has the capacity to "make an administration do something it would not otherwise do." As represented in figure 1.3, the administration (A) may be more inclined to cater to business interests if $\mathrm{B}$ can (threaten to) move to exit option $\mathrm{E}$ where corporate taxation is low. Reversely, the abilities that B has to lay off workers or move abroad may be significantly conditioned in times of economic boom, depression, war, natural disasters, or epidemics (D) as represented in figure 1.4. The degree and efficacy of business power is then dependent upon a multitude of direct power relations that vary over time. In sum, while various manifestations of structural power are represented in figure 1, none of the power relationships are (theoretically) unobservable or cannot be studied as a constellation of dyadic power relations.

This basic framework becomes more complex when we also take ideational structural power into account, for example factors such as perceptions, ideas, and discourses and how those are shaped. Yet, as articulated by the various scholars working in this tradition, even dominant ideas and 


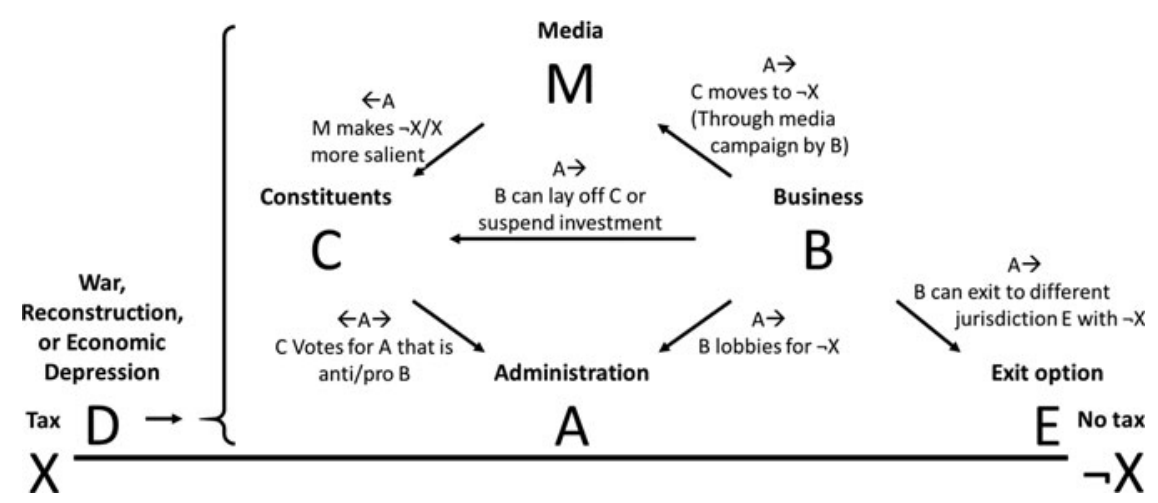

Figure 2: Visualization of the working mechanisms of business power through constellations of dyadic power relations.

perceptions are malleable and subject to change due to the agency of certain actors. ${ }^{47}$ We account for such influences by adding the factor $\mathrm{M}$ to our model. In a narrow sense this $\mathrm{M}$ stands for media, but one may also consider pundits, experts, and research institutions (such as universities) whose societal influence is often exercised through media outlets. Figure 1.5 represents the argument by Culpepper that increased media attention is likely to result in more opposition on behalf of constituents $(\mathrm{M} \Rightarrow \mathrm{C} \Rightarrow \mathrm{A}){ }^{48}$ while figure 1.6 also demonstrates how business may use the media to win support for its position $(B \Rightarrow M \Rightarrow C \Rightarrow A){ }^{49}$

\section{A unified basic framework for studying business power}

All direct and indirect relations through which business can exercise power over the state and influence policies as separately discussed in the previous section are integrated in figure 2 . The power relation between business and an administration as articulated by instrumentalists $(B \Rightarrow A)$ is supplemented by three alternative instrumental capacities that business has at hand to influence policies. Business can threaten to move to a different jurisdiction as long as an exit option exists $(B \Rightarrow E)$; it can threaten to suspend investment or fire workers who may express their dissatisfaction at the next election $(B \Rightarrow C \Rightarrow A)$; or it may influence the very same electorate using the media $(B \Rightarrow M \Rightarrow C \Rightarrow A)$. All relations may be strengthened or weakened by special circumstances such as economic recessions, war, natural disasters, or epidemics (factor D). Such circumstances also severely constrain the abilities of A to change policies and eventually also of $\mathrm{B}$ to move abroad.

Three remarks are important regarding the visual representations in the figures. First, the dyadic power relationships (instrumental capacities) represented by the arrows can be hypothesized in both directions. ${ }^{50}$ Business may have power over workers (or constituents) or the state, but reversely state administrations also have a variety of instruments to limit business power, and employees may exert power over business through unionization and strikes. Because our goal in this article is to understand how business exerts power over the state, the arrows point away from business. Second, it is important to understand that neither business, media, or constituents are unitary actors. ${ }^{51}$ In fact, voters are a heterogeneous group, and businesses may consist of rivaling factions that have diverging interests, with some having more leverage than others. Even legislators or administrations are likely to be internally divided. ${ }^{52}$ In addition, the composition of administrations will fluctuate over time and include sometimes probusiness parties that tilt the whole administration toward one side or the

\footnotetext{
${ }^{47}$ See Bell (2012); Fairfield (2015b).

${ }^{48}$ Culpepper (2011).

${ }^{49}$ Marsh et al. (2014).

${ }^{50}$ See, e.g., Culpepper (2015); Marsh (1983).

${ }^{51}$ Vogel (1987); see also Poulantzas (1968).

${ }^{52}$ Smith $(1999,861)$.
} 
other when they enter or leave the government (as we also describe in our case study). The positions regarding a particular tax that are presented in the models, should thus be regarded as the aggregate position taken by either the administration (A), business (B), or constituents (C) in this specific case. They are all potentially subject to change (in other cases or over time). Third, this framework should be seen as an elementary model that can easily be expanded by adding more power relations. Such a simplified model leaves open the possibility to introduce additional complexity or power relationships depending on the case under investigation.

Our framework represented in figure 2 hence enables us to study business power in its various forms by examining the (perceived) strength of the underlying dyadic power relations. In our conceptualization, structural power thus stems from the perceived availability of various dyadic instrumental capacities on behalf of business. Variation in business power can be explained through the increase, decrease, or vanishing of dyadic power relations. Some of these capacities will be rather stable: a firm may always have the capacity to fire workers or suspend investment. At the same time, the credibility that it will do so depends crucially on the economic circumstances and future expectations. In such circumstances, information and information asymmetries can play a key role. ${ }^{53}$ Following our framework, explaining business power does not need to rely on structural power as only an abstract phenomenon: the different mechanisms through which business power is exercised can be captured by the various described dyadic power relations. In fact, business would have little leverage through only direct instrumental power $(B \Rightarrow A)$ such as lobbying, if the indirect power relations were not in place-for example, if businesses lack credible potential to fire workers, move abroad, or influence media campaigns. ${ }^{54}$ In this sense, our conceptualization of business power recalibrates the often rigid distinction between instrumental and structural power relations by shifting the focus to its underlying dyadic power relations.

\section{The case of the Dutch dividend tax debate}

In this section we put our framework to work by applying it to an empirical case study on the Dutch dividend tax debate over the last years. We will do so by closely tracing the changing instrumental and structural power relations between business and other societal actors over time. Such an approach that investigatively excavates the cross-temporal dynamics avoids the problem of what Hacker and Pierson called "relying on post-hoc correlations." They hold that to demonstrate the efficacy of business power, one "must not only show that outcomes are congruent with the preferences of specific actors" but also that it is necessary to "demonstrate that these outcomes are a result of the actors direct or indirect power." 55 Hence, evidencing the mechanisms through which instrumental and (material or ideational) structural power affect real-world outcomes leverages the explanatory purchase of a business power framework.

In selecting our case we followed the criteria set by Culpepper that enable researchers to demonstrate the existence of both instrumental and (in particular) structural forms of business power. He lists three criteria that a case should satisfy. First, structural power is most likely to be found "where it pushes against substantial opposition in government or in public opinion." ${ }^{56}$ If preferences of business correlate with public opinion, it is difficult to demonstrate structural influence. Second, he argues that research should "specify the sources of variation in structural power and show how that variation helps account differences in outcomes." 57 Thus, one needs to widen the spatial or temporal horizon to explain why a certain outcome is reached at one particular moment or place (and which factors account for that). Finally, Culpepper emphasizes the need to distinguish structural from instrumental power in terms of operationalization. ${ }^{58}$ In our case this means that one distinguishes the direct

\footnotetext{
${ }^{53}$ Bernhagen and Bräuninger (2005).

${ }^{54}$ Woll (2016).

${ }^{55}$ Hacker and Pierson $(2002,285)$.

${ }^{56}$ Culpepper $(2015,397)$.

${ }^{57}$ Ibid.

${ }^{58}$ Ibid.
} 
relations between business and the state from the indirect (perceived) relations such as the existence of exit options, the risk of layoffs, and the role of media and experts.

The case study shows how the application of our framework satisfies all criteria set by Culpepper. We analyze how the Dutch administration led by Prime Minister Mark Rutte agreed on the abolishment of the dividend tax favoring business in 2017 and held onto it for a year despite overwhelming opposition from public opinion and significant opposition in government. ${ }^{59}$ The abolishment would have been a prime example of a government catering to the interest of big business, as the measure would have benefited large listed companies in the Netherlands, while simultaneously tearing a hole of almost $€ 2$ billion in the national budget. ${ }^{60}$ Using our framework we demonstrate the changes of business power that led to the (temporal) variation in outcomes: Why did earlier administrations not decide to cut taxes and why did the Rutte administration ultimately backtrack on its decision? We demonstrate how the gradual erosion of the structural power of Dutch multinationals in the period of 2017-18 only tilted the government toward non-abolishment once it became clear that the Anglo-Dutch firm Unilever could not move headquarters. The various working mechanisms identified in the preceding discussion could be described as rivaling hypotheses on how a certain outcome is achieved. However, as we emphasize in the following, only multiple changes in saliency, expert judgments, public opinion, and opposition within government taken together resulted in the specific outcome we describe-while by themselves they proved to be insufficient conditions over those years. Therefore, instead of relying on post hoc correlations alone, and eliminating "rivaling" explanations, we trace and excavate the various dynamics of business power in our case study, and integrate and leverage their explanatory power in the following.

\section{Before the debate: The constellations (dis)favoring business power}

The history of the abolishment of the Dutch dividend tax goes back at least until 2005, when the government decided to lower the dividend tax from 25 to 15 percent, and a junior minister of finance claimed that in the long run, the tax would be abolished completely. ${ }^{61}$ At that point a business-friendly ruling coalition consisting of the Christian-democratic CDA, the conservative-liberal VVD, and the social-liberal D66 was in place. In this environment, Dutch big business took the opportunity to lobby constantly for the complete abolishment of the tax.

This came to the surface in 2009, when the Dutch employer's association VNO-NCW released a report about the need to attract corporate headquarters to the Netherlands, written by academics from the Rotterdam School of Management. The VNO-NCW leader called the dividend tax a "monster" that had to go, while Prime Minister Balkenende responded that he was aware of the wishes of business, but didn't act upon the requests. ${ }^{62}$ Later, investigative journalists and activists found out that the report was likely paid for by Shell, ${ }^{63}$ which exemplifies an occasion of the usage of instrumental power resources to shape perceptions-in this case through the employers' organization $(B \Rightarrow M \Rightarrow C \Rightarrow A$ in our framework).

Meanwhile, the measure was lobbied by the ABUP-club of the "big four" Dutch nonfinancial multinationals: AkzoNobel, Royal Dutch/Shell, Unilever, and Philips. ${ }^{64}$ In a letter as well as visits to the state secretary of finance, some ABUP members suggested as early as 2007 that the dividend tax could be terminated by a procedure of urgent treatment already in $2008,{ }^{65}$ when the global financial crisis hit.

\footnotetext{
${ }^{59}$ The dividend tax is a withholding tax levied when corporations distribute dividends to its shareholders. Because Dutch shareholders could already deduct the tax paid from their income tax, only foreign shareholders were effectively profiting from its abolishment.

${ }^{60}$ Kok and Hoedeman (2018).

${ }^{61}$ de Witt Wijnen (2018).

${ }^{62}$ van Teeffelen (2017).

${ }^{63}$ Bollen (2018).

${ }^{64}$ The ABUP (sometimes also ABDUP, including Royal DSM) is a relatively secretive forum of the mentioned Dutch multinationals that, since after World War II, regularly meets for strategic and lobbying reasons.

${ }^{65}$ Niewold (2018).
} 
Balkenende's political end came in 2010, when Mark Rutte took over as prime minister. After two months in office, the ABUP members renewed their lobbying efforts, including personal meetings with Rutte. $^{66}$ The Dutch department of the American Chamber of Commerce (AmCham) joined these efforts by advocating the abolishment to state officials directly and sending out information in 2011, 2013, 2014, 2015, and 2017. ${ }^{67}$ Additionally, document revelations showed that the abolishment was discussed in internal memos of the ruling VVD and during dinners of ministers with business organizations. $^{68}$

Why then, did the government not follow through on the abolishment? The most reasonable explanation is that the fourth Balkenende Cabinet (2007-10) and the second Rutte Cabinet (2012-17) were restrained to act accordingly because they were in coalition with the Labour Party (PvdA), which did not support the abolishment and later even became one of its fiercest opponents. After the 2006 and 2012 elections, it had become virtually impossible to create a governing coalition without any left-wing party. Following our model in figure 2, voters $(C \Rightarrow A)$ had determined that the administration could not move in the direction of no tax (-X).

In this sense, it was only during the first Rutte Cabinet (2010-12), which consisted of VVD and CDA, supported by the right-wing populist PVV, that the theoretical opportunity for abolishment was given. However, the start of this coalition government coincided with the economic downturn resulting from the global financial crisis and the subsequent European sovereign debt crisis. The Netherlands, as many other European countries, were affected by this, for example through a high-cost saving and nationalization of the ABN-AMRO bank. There was hence little budgetary space for tax breaks to business, as the government was already cutting severely on expenses. Although the first Rutte Cabinet was one of the most right-wing administrations the Netherlands has ever seen, business power was constrained by the circumstantial factor of the global recession, in our model represented by factor D.

The next opportunity for the tax to be abolished was after the 2017 national elections, in which the left-wing parties together incurred dramatic electoral losses and VVD, CDA, D66, and Christian Union (ChristenUnie) agreed to form a coalition. The government plans for this new center-right coalition were officially announced on October 10, 2017, together with the announcement of the abolishment of the dividend tax. This announcement came as a surprise to many because it had not been in the party platforms of any of the governing parties.

Journalistic investigation suggested first that the measure came from the employers' organization VNO-NCW, but it soon became clear that it had been mainly the Dutch-British multinationals Shell and Unilever that had contacted politicians and government officials to lobby the measure. ${ }^{69}$ These big multinationals, particularly Unilever, had much leverage over the government at this point: several weeks before the election, both AkzoNobel and Unilever had been subject to attempts of hostile takeovers by the American firms PPG and Kraft-Heinz, respectively. This had triggered renewed concerns about the eventual loss of Dutch "national champions" to foreign investors. Both firms were able to avert the takeover, but in the case of AkzoNobel only by selling its whole chemical business worth more than $\$ 10$ billion. $^{70}$

Unilever also secured support from its shareholders to remain independent, but it pledged to revise its corporate structure. Until then, Unilever consisted of two separate Dutch and British companies, but it planned to become a single company that would either be headquartered in the United Kingdom or in the Netherlands. As a result, the company could bring this exit option to the table when lobbying either the British or the Dutch government. This "credible threat," which is represented by relation $\mathrm{B} \Rightarrow \mathrm{E}$ in our framework, has been absent in earlier years.

\footnotetext{
${ }^{66}$ Lukassen and Pauw (2018).

${ }^{67}$ van Teeffelen (2017).

${ }^{68} \mathrm{Ibid}$.

${ }^{69}$ NOS (2017).

${ }^{70}$ Sterling and Meijer (2018).
} 
The general conditions for business power were thus highly favorable in 2017. There was no genuinely left party in government. Moreover, the economy was doing well and had not been a salient theme during the election campaign. Thus, according to our model, we would indeed expect the government to move in the direction of business interest as it did in the following months.

\section{The start of the debate: (Re)shaping perceptions}

From November 2017 onward the abolishment was publicly singled out as one of the strangest measures the cabinet proposed, and ministers were repeatedly called to defend the measure in parliament. In the beginning, mainly left-wing parties put the issue on the agenda, claiming that the government puts multinationals before people. They also challenged the undemocratic character of the measure because it had not been mentioned in any election platform. Many journalists followed this reasoning and helped to increase the saliency of the measure, thereby shaping public opinion negatively toward the planned abolishment ( $M \Rightarrow C$ in our framework).

Nevertheless, Rutte and his cabinet were keen on defending the measure, even despite growing parliamentary and public resistance. They drew on different arguments reflected in our framework. First of all, they often employed the argument that abolishing the tax was crucial for the business climate of the Netherlands, as businesses would otherwise leave the country $(B \Rightarrow E)$. In an often-cited passage the prime minister stated:

If we do not do this, if we do not keep the Netherlands attractive in this big international competition, we will price ourselves out of the market. That I believe to my innermost fibers, that I am absolutely convinced of. I agree ... that there should not be a race to the bottom ... but if we do not do this it will cost jobs. Then we will get what also happened in Belgium, where, aside from InBev, all big companies have meanwhile left. I do not want to let that happen. ${ }^{71}$

In response, the opposition referred to the Central Planning Bureau, ${ }^{72}$ which claimed that abolishing the tax would have no positive effect on employment. On the question where Rutte based the effectiveness of the measure on, he responded:

Of course, abolishing the dividend tax or lowering corporate taxes will not or hardly be visible in the models of the Central Planning Bureau. I do understand that. Fact is, that the United Kingdom, which soon leaves the European Union, does not have a dividend tax. If we see that other countries in the EU don't have a dividend tax and we see large economies such as France lowering their corporate taxes to $25 \%$, then we cannot sit still. If you do this ... you take an irresponsible risk with Dutch jobs. ${ }^{73}$

This passage demonstrates how Rutte, in fact, was willing to engage in a "race to the bottom," but he was clearly conflating the (effectiveness of the) dividend tax with other corporate taxes, for which evidence of a positive correlation between lower rates and investment increases existed. This evidence was lacking for the dividend tax. Later, when the board of Unilever announced its plans to locate its headquarters to the Netherlands, it was strongly disputed publicly whether the move will create any measurable employment at all in the Netherlands $(B \Rightarrow C) .^{74}$

In the quoted passages, Rutte refers explicitly to international developments such as Brexit to shape the general perception that the measure was necessary. This reflects the later admission by the Unilever CEO that the tax abolishment was a precondition for moving to the Netherlands. ${ }^{75}$ In an effort to gain

\footnotetext{
${ }^{71}$ Translated from Rutte $(2017,7)$.

${ }^{72} \mathrm{~A}$ government-sponsored think-tank that makes predictions about the impact of policies on the economy.

${ }^{73}$ Translated from Rutte $(2017,9)$.

${ }^{74}$ NOS (2018).

${ }^{75}$ van Dongen and van Mersbergen (2018).
} 
support amongst constituents, Rutte relied on a general formula of international competition and past experiences to shape perceptions in favor of abolishment. At the same time, opposition parties could draw on expert knowledge that did not support the claim that abolishing the dividend tax would lead to new jobs.

To unite business behind the measure, a key argument in the debate was that also smaller companies such as cab companies and hotels, benefitted from the presence of multinationals in the Netherlands. In a parliamentary hearing, the CEO of Shell Nederland, for instance, said that Shell was responsible for 100,000 hotel stays each year, which was verified by journalists. ${ }^{76}$ Such arguments can be regarded as deliberate efforts to create business unity to support the measure.

\section{The persisting saliency of the abolishment}

During the campaign for the Dutch municipality elections in 2018, the dividend tax was often brought up by opposition parties. Around the same time, the management of Unilever announced that they would (re)locate their headquarters to Rotterdam, but their British shareholders still needed to approve of the plans. Opposition parties stated that the decision proved that there was no need to abolish the dividend tax, while Unilever's supervisory board chairman Martijn Dekkers declared he assumed the same tax regime in the United Kingdom and the Netherlands. ${ }^{77}$

The pressure on Rutte reached its peak in April 2018, when it became public that the coalition had based its decision to abolish the dividend tax on a number of internal memos, of which it had denied any existence during an earlier debate in November $2017 .^{78}$ Due to increasing political pressure, the coalition publicly revealed the memos. Shortly after, news reports exposed that key actors in the coalition negotiations were aware of the existence of those documents. ${ }^{79}$ Moreover, it became clear that Shell and Unilever were consulted during the coalition talks, which reinforced the image of a lobbied measure. Attacks from political opponents and other actors notwithstanding, the government seemed resolute to push the measure through at all costs.

These revelations were grist to the mills for the parliamentary opposition that was now unanimously challenging Rutte's handling of the issue. The topic dominated the parliamentary debates as well as the financial press for the following months of 2018. While the cabinet defended the measure by emphasizing the structural dependence of constituents on the presence of big multinationals in the country, the opposition criticized the lobby efforts and revolving doors typically associated with instrumental power. The media was increasingly taking side with the opposition $(M \Rightarrow C \Rightarrow A$ in our framework). This was in part due to the secrecy surrounding the measure but also because the government was not able to convincingly evidence the effectiveness of the policy.

In August 2018, it became clear that the estimated revenue loss as a consequence of the abolishment would be even higher than anticipated in the annual household budget ( $€ 1.9$ billion instead of $€ 1.4$ billion). ${ }^{80}$ While the passive support from the other coalition parties was eroding, the government stuck to its plans as the VVD threatened to resign from the coalition if the other parties would not comply. If at any point the government wished to backtrack on its decision to avoid credibility loss, this would have been the moment. Rutte, in an attempt to reframe public discontent, even called the abolishment a "bizarre measure" because "no one would give tax advantages to foreign investors just for fun." ${ }^{81}$ Yet he also claimed it was still necessary and the cabinet ultimately settled on abolishing the tax.

At this point, also small and medium-sized companies expressed their dissatisfaction, while AmCham, which had earlier even lobbied the measure, also withdrew support. ${ }^{82}$ Business thus got

\footnotetext{
${ }^{76}$ Bosman (2018).

${ }^{77}$ Dekker (2018).

${ }^{78}$ Brandsma and Kleinnijenhuis (2018).

${ }^{79}$ Jonker (2018).

${ }^{80}$ Kok and Hoedeman (2018).

${ }^{81}$ NU.nl (2018).

${ }^{82}$ Klop (2018).
} 
disunited, while public opinion became even more opposed. Opinion polls in September indicated that now only 13 percent of the electorate supported the measure, down from 25 percent in November 2017 and 18 percent in April 2018. ${ }^{83}$ Some prominent former party leaders of D66 and even from the VVD openly opposed the measure, and yet the government persisted in its decision and retained majority support for the abolishment.

\section{The resilience of material structural power: No Unilever, no abolishment}

Until October 2018 the government persistently relied on arguments associated with structural power of business by emphasizing that catering to the interests of multinationals is necessary because they provide jobs and that they might leave the country if the dividend tax remained in place. In our framework these are the perceived relations that business has over constituents $(B \Rightarrow C)$ and of the ability of business to move to a different country $(B \Rightarrow E)$.

At the same time, the government was reluctant to admit that the proposal was the result of successful lobby efforts on behalf of business $(B \Rightarrow A)$ as this would indicate that the government would let its policies be dictated by the special interests of big business. Nevertheless, this became the dominant narrative in the media, which resulted in public opinion becoming ever more opposed to the measure $(\mathrm{M} \Rightarrow \mathrm{C})$. Especially for the more centrist coalition parties such as D66 and the Christian Union it also translated into a loss of support in opinion polls $(C \Rightarrow A)$.

The increasing saliency and opposition were perhaps necessary, but insufficient to make the government revoke its plans. In fact, it was a shareholder revolt at Unilever that dealt the final blow to the government's plans. On October 5 it was revealed that Unilever's shareholders voted against the plans of management to move to Rotterdam and expressed their will to stay in the United Kingdom to avoid being dismissed from the FTSE100 index. This dismissal would automatically delist Unilever from a range of important index tracking funds, which would in turn decrease the company's share value.

Once this decision became clear, it took the Dutch government only a few hours before it announced it would "reconsider" the tax abolishment plans. Rutte stated that Unilever was an important "testcase" for the measure that had failed because Unilever would remain in the United Kingdom. ${ }^{84}$ The abolishment was dropped a few days later when it was announced that the government was planning other, less contentious corporate tax breaks instead. ${ }^{85}$ In sum, the strong resistance of the government in the face of overwhelming societal opposition was only broken once the last instrumental straw-Unilever's de facto exit option-fell through. The removal of an important instrumental capacity of business $(B \Rightarrow E)$ made it impossible for the Rutte government to uphold the perception of the structural power of business necessitating the tax abolishment. According to our framework, the following withdrawal was the only remaining strategic option in this situation.

\section{Discussion and conclusion}

What can we learn from this case study? We have concluded in our account that the failed abolishment can be most convincingly explained by the fact that Unilever, as the key multinational in the debate, could no longer pressure the government by promising to move to Rotterdam as a quid pro quo for abolishing the tax. Due to the decision of the firm's shareholders, the Unilever management lost one of its crucial "instruments"-that is, moving headquarters-for pressuring the government. While a version of this argument-Unilever's structurally advantageous position changed-is typically associated with structural power explanations, it is neither abstract nor "unobservable." The loss of the instrument of moving headquarters dealt the final blow to the long-upheld (structural) perception of the government that the measure was necessary to attract the jobs associated with a move of a multinational to

\footnotetext{
${ }^{83}$ Rademaker (2018).

${ }^{84}$ Rutte (2018).

${ }^{85}$ Ibid.
} 
the Netherlands. While the expert analysis, the media and the public almost unanimously disputed this argument for a while, it was now no longer tenable for the Rutte government to uphold and politically employ this specific perception of the need to cater to big business.

Our framework facilitates this analysis by integrating various accounts that aim to understand the dynamics of state-business relations. We demonstrated how the changing positions of the Dutch government can be traced back to different constellations of dyadic power relations, some of which are more material and others that are more ideational in nature. The framework therefore does not advocate for one specific factor or explanation for the outcome over others. Instead, it synthesizes a set of insights from different accounts, and enables researchers to recognize the varying influence of multiple power relations leading to particular outcomes, even when some power relations are not decisive in the last instance but play an important role in the process.

What does this mean for business power research? A decade after the Great Recession, research efforts into better understanding business power are in full swing. The theoretical and empirical applications of instrumental and structural power approaches have yielded important insights into how business leverages different resources and how other societal actors respond to this agency. So-called hybrid approaches are thereby especially valuable because they aim to fine-tune our analytical instruments to better grasp variation, change, and further dynamics involved in the exercise of business power. At the same time, these hybrid approaches lacked a unified framework that integrates instrumental and structural power arguments and the burgeoning insights from ideational power research.

Our contribution aimed to systematize the various contributions and integrate them into a basic framework. The empirical case study we conducted demonstrates how such an approach can be readily applied to cases of business power, especially when there is temporal variation in outcomes and economic dynamics change during the process. As our case illustrated, the unexpected outcome of the Dutch dividend tax debate presents a problem for classical instrumental as well as structural power arguments. Lobbying was persistently high, and the perceptions of government officials were tilted toward the idea that big business played a vital role for the economy. The fact that both sources of power were not able to realize the abolishment indicates that we need to pay closer attention to variation and change in business power over time. Our suggested framework emphasized their co-constitution and thus leveraged both forms of business power to provide a robust explanation for the observed outcome.

Like any other model, our framework is an analytically necessary simplification of a more complex reality. As already pointed out, neither of the mentioned actors-businesses, media outlets, constituents, and even administrations-are unitary actors; and perceptions as well as power relations are not static, but dynamically built up over time and informed by earlier experience. By introducing such a more intertemporal and nuanced perspective, business power analysis can move from a snapshot-like constellation of power relations to a more complex network understanding of these relations. In this article, we already laid the foundations for such a complex understanding by conceptualizing structural power as a constellation of dyadic power relations. Building on this, business power can be understood as a complex phenomenon, which emerges through the interplay of more simple, underlying relations. ${ }^{86}$ According to this notion, "lower-level components"-for example, dyadic power relations between various actors-interact to produce "higher-level" phenomena-in our case the (structural) power of business. Our contribution can serve as a first theoretical and empirical step into building analytical tools utilizing complex systems mechanisms as developed in other fields. We hope our model provides a useful analytical tool for empirical research that can and should be applied, criticized, and extended in further scholarship. The simplified nature of our model invites future research to modify and adapt it to the case under scrutiny, also to better understand business power beyond the domestic context.

\footnotetext{
${ }^{86}$ Gershenson and Fernández $(2012,31)$.
} 


\section{References}

Baars, Grietje, and André Spicer, eds. 2017. The Corporation: A Critical, Multi-Disciplinary Handbook. Cambridge University Press.

Babic, Milan, Jan Fichtner, and Eelke M. Heemskerk. 2017. "States versus Corporations: Rethinking the Power of Business in International Politics." The International Spectator 52 (4): 20-43.

Barrow, Clyde W. 1993. Critical Theories of the State: Marxist, Neo-Marxist, Post-Marxist. University of Wisconsin Press.

Bell, Stephen. 2012. "The Power of Ideas: The Ideational Shaping of the Structural Power of Business: The Power of Ideas." International Studies Quarterly 56 (4): 661-73.

Bell, Stephen, and Andrew Hindmoor. 2014. "The Structural Power of Business and the Power of Ideas: The Strange Case of the Australian Mining Tax." New Political Economy 19 (3) 470-86.

Bell, Stephen, and Andrew Hindmoor. 2017. "Structural Power and the Politics of Bank Capital Regulation in the United Kingdom.” Political Studies 65 (1): 103-21.

Bernhagen, Patrick, and Thomas Bräuninger. 2005. "Structural Power and Public Policy: A Signaling Model of Business Lobbying in Democratic Capitalism.” Political Studies 53 (1): 43-64.

Bollen, Thomas. 2018. "Door Shell Gefinancierd Onderzoek Stond Aan de Basis van Afschaffing Dividendbelasting." Follow the Money. https://www.ftm.nl/artikelen/shell-rsm-onderzoek-dividendbelasting

Bosman, Suzanne. 2018. Feit of Fictie: Shell Levert Nederland 100.000 Hotelkamerovernachtingen Op. NPO Radio 1. https:// www.nporadio1.nl/radio-eenvandaag/onderwerpen/14919-2017-12-15-feit-of-fictie-shell-levert-nederland-100-000-hotelkamerovernachtingen-op

Brandsma, Jelle, and Jan Kleinnijenhuis. 2018. “Toch Memo’s over Omstreden Afschaffing van Dividendbelasting." Trouw. https://www.trouw.nl/nieuws/toch-memo-s-over-omstreden-afschaffing-van-dividendbelasting b62b1b82/

Burris, Val. 1987. "The Political Partisanship of American Business: A Study of Corporate Political Action Committees." American Sociological Review 52 (6): 732-44.

Culpepper, Pepper D. 2011. Quiet Politics and Business Power: Corporate Control in Europe and Japan. Cambridge University Press.

Culpepper, Pepper D. 2015. "Structural Power and Political Science in the Post-Crisis Era." Business and Politics 17 (3): $391-409$.

Culpepper, Pepper D., and Raphael Reinke. 2014. "Structural Power and Bank Bailouts in the United Kingdom and the United States." Politics \& Society 42 (4): 427-54.

Dekker, Wilco 2018. "Waarom Unilever Londen voor Rotterdam verruilt." De Ondernemer. https://www.deondernemer.nl/ actueel/horeca/waarom-unilever-londen-rotterdam-verruilt $\sim 273975$.

De Witt Wijnen, Philip. 2018. "Dit Staat Er in de Memo's over de Afschaffing van de Dividendbelasting." NRC. https://www.nrc. nl/nieuws/2018/04/25/dit-staat-er-in-de-memos-over-de-afschaffing-van-de-dividendbelasting-a1600788

Fairfield, Tasha. 2015a. "Structural Power in Comparative Political Economy: Perspectives from Policy Formulation in Latin America." Business and Politics 17 (3): 411-41.

Fairfield, Tasha. 2015b. Private Wealth and Public Revenue in Latin America. Cambridge University Press.

Fuchs, Doris. 2013. “Theorizing the Power of Global Companies.” In Handbook of Global Companies, edited by John Mikler, 77-95. Wiley-Blackwell.

Fuchs, Doris, and Markus Lederer. 2007. "The Power of Business.” Business and Politics 9 (3): 1-17.

Gershenson, Carlos, and Nelson Fernández. 2012. "Complexity and Information: Measuring Emergence, Self-Organization, and Homeostasis at Multiple Scales.” Complexity 18 (2): 29-44.

Getz, Kathleen A. 1997. "Research in Corporate Political Action: Integration and Assessment." Business \& Society 36 (1): $32-72$.

Hacker, Jacob S., and Paul Pierson. 2002. "Business Power and Social Policy: Employers and the Formation of the American Welfare State." Politics \& Society 30 (2): 277-325.

Haugaard, Mark 2014. "Power." In The Encyclopedia of Political Thought, edited by Michael T. Gibbons, 1-13. Wiley-Blackwell. Hindmoor, Andrew, and Josh McGeechan. 2013. "Luck, Systematic Luck and Business Power: Lucky All the Way Down or Trying Hard to Get What It Wants without Trying?" Political Studies 61 (4): 834-49.

Jonker, Jorn 2018. “Wiebes Kreeg Memo Dividendbelasting Wél.” De Telegraaf Online. https://www.telegraaf.nl/nieuws/1948828/ wiebes-kreeg-memo-dividendbelasting-wel

Klop, Wesley 2018. “Amerikaans-Nederlands Bedrijfsleven Tegen Afschaffing Dividendbelasting.” Algemeen Dagblad. https:// www.ad.nl/binnenland/amerikaans-nederlands-bedrijfsleven-tegen-afschaffing-dividendbelasting ad0c8160/.

Kok, Laurens, and Jan Hoedeman. 2018. "Einde Dividendbelasting Wordt Nóg Duurder.” Algemeen Dagblad. https://www.ad.nl/ politiek/einde-dividendbelasting-wordt-nog-duurder a06257b1/

Lindblom, Charles Edward. 1977. Politics and Markets: The World's Political-Economic Systems. BasicBooks.

Lukassen, Rene, and Matthias Pauw. 2018. "Rutte Vanaf Zijn Aantreden Bezig Met Afschaffen Dividendbelasting." RTL Nieuws. https://www.rtlnieuws.nl/economie/artikel/4410176/dividendbelasting-afschaffen-rutte-acht-jaar-shell-unilever?redirect_from=rtlz

Marsh, David. 1983. "Interest Group Activity and Structural Power: Lindblom's Politics and Markets.” West European Politics 6 (2): 3-13.

Marsh, David, Sadiya Akram, and Holly Birkett. 2015. "The Structural Power of Business: Taking Structure, Agency and Ideas Seriously." Business and Politics 17 (3): 577-601.

Marsh, David, Chris Lewis, and Jenny Chesters. 2014. "The Australian Mining Tax and the Political Power of Business." Australian Journal of Political Science 49 (4): 711-25. 
Miliband, Ralph. 1969. The State in Capitalist Society. Basic Books.

Niewold, Michael. 2018. "Mails, Bezoeken En Praten Met de Benen Op Tafel: 15 Jaar Bedelen Om Afschaffing Dividendtaks." RTL Nieuws. https://www.rtlnieuws.nl/economie/artikel/4412366/dividendtaks-afschaffing-lobby-vvd-rutte-unilever-shell

NOS. 2017. "Shell en Unilever hebben voor afschaffing dividendbelasting gelobbyd." NOS Nieuwsuur. https://nos.nl/nieuwsuur/ artikel/2201913-shell-en-unileverhebben-voor-afschaffing-dividendbelasting-gelobbyd.html

NOS. 2018. “Unilever kiest voor Rotterdam, wat hebben we eraan?” NOS Nieuwsuur. https://nos.nl/nieuwsuur/artikel/2222579unilever-kiest-voor-rotterdam-wathebben-we-eraan.html

NU.nl. 2018. "Rutte Noemt Afschaffen Dividendbelasting 'Bizarre Maatregel.” NU.nl. https://www.nu.nl/politiek/5422625/ruttenoemt-afschaffen-dividendbelasting-bizarre-maatregel.html

Poulantzas, Nicos. 1968. Political Power and Social Classes. Verso.

Przeworski, Adam, and Michael Wallerstein. 1988. "Structural Dependence of the State on Capital." The American Political Science Review 82 (1): 11-29.

Rademaker, Gijs. 2018. “Stemmers D66, CDA en ChristenUnie over de VVD: We worden Beduveld." EenVandaag/AVRO/TROS. https://eenvandaag.avrotros.nl/panels/opiniepanel/alle-uitslagen/item/stemmers-cda-d66-

Richardson, Jeremy. 2000. “Government, Interest Groups and Policy Change.” Political Studies 48 (5): 1006-25.

Rutte, Mark. 2017. "Regeringsverklaring 2. November 2017 (government policy statement).” https://zoek.officielebekendmakingen.nl/h-tk-20172018-17-2.pdf

Rutte, Mark. 2018. "Premier Rutte Legt Uit Waarom Dividendbelasting Niet Afgeschaft Wordt.” NU.nl. https://www.nu.nl/ 250709/video/premier-rutte-legt-uit-waarom-dividendbelasting-niet-afgeschaft-wordt.html

Smith, Mark A. 1999 "Public Opinion, Elections, and Representation within a Market Economy: Does the Structural Power of Business Undermine Popular Sovereignty?" American Journal of Political Science 43 (3): 842-86.

Sterling, Toby, and Bart H. Meijer. 2018. “Akzo Nobel Reshapes Business with 10 Billion Euro Sale.” Reuters. https://www.reuters. com/article/us-akzo-nobel-divestiture-carlyle-group/akzo-nobel-reshapes-business-with-10-billion-euro-sale-idUSKBN1H30KL

Van Dongen, Annemieke, and Sander van Mersbergen. 2018. "Topman Unilever: Afschaffen Dividendbelasting Was Onze Harde Eis." Algemeen Dagblad. https:/www.ad.nl/politiek/topman-unilever-afschaffen-dividendbelasting-was-onze-harde-eis a 51472e5/

Van Teeffelen, Jasper. 2017. "De Dag Die Je Wist Dat Ging Komen: Jarenlange Lobby Multinationals Eindelijk Beloond Met Afschaffen Dividendbelasting." SOMO Opinie. https://www.somo.nl/nl/afschaffing-dividendbelasting-na-jarenlange-lobbydoor-vno-ncw/

Vogel, David. 1987. "Political Science and the Study of Corporate Power: A Dissent from the New Conventional Wisdom.” British Journal of Political Science 17 (4): 385-408.

Woll, Cornelia. 2016. "Politics in the Interest of Capital: A Not-so-Organized Combat.” Politics \& Society 44 (3): 373-91.

Wright, J. R. 2003. Interest Groups And Congress: Lobbying, Contributions, and Influence. Pearson Longman.

Young, Kevin. 2015. "Not by Structure Alone: Power, Prominence, and Agency in American Finance." Business and Politics 17 (3): 443-72.

Jouke Huijzer, Department of Political Science, Free University Brussels; Pleinlaan 2, 1050 Brussels, Belgium. Email: jouke. huijzer@vub.ac.be

Javier Garcia-Bernardo, Social and Behavioural Sciences, Social Data Science (SoDa) Team, Utrecht University; Amsterdam Institute for Social Science Research, University of Amsterdam; Heidelberglaan 1, 3584 CS Utrecht, The Netherlands. E-mail: j.garciabernardo@uu.nl

Diliara Valeeva, Department of Geography and Tourism, KU Leuven; Celestijnenlaan 200e, 3001 Leuven, Belgium. E-mail: diliara.valeeva@kuleuven.be

Cite this article: Babic M, Huijzer J, Garcia-Bernardo J, Valeeva D (2022). How does business power operate? A framework for its working mechanisms. Business and Politics 24, 133-150. https://doi.org/10.1017/bap.2021.19 